\title{
Applying the Ignatian pedagogical paradigm to the creation of an accounting ethics course
}

\author{
Dawn W. Massey \\ Fairfield University, dmassey@fairfield.edu \\ Joan Lee (Van Hise) \\ Fairfield University, jlee@fairfield.edu
}

Follow this and additional works at: https://digitalcommons.fairfield.edu/business-facultypubs This is a post-print of an article published in Journal of Business Ethics. The original publication is available at http://www.springerlink.com.

\section{Peer Reviewed}

\section{Repository Citation}

Massey, Dawn W. and Lee (Van Hise), Joan, "Applying the Ignatian pedagogical paradigm to the creation of an accounting ethics course" (2008). Business Faculty Publications. 15.

https://digitalcommons.fairfield.edu/business-facultypubs/15

\section{Published Citation}

Van Hise, Joan and Dawn W. Massey. 2008. Applying the Ignatian pedagogical paradigm to the creation of an accounting ethics course. Journal of Business Ethics 96 (3), 453-465.

This item has been accepted for inclusion in DigitalCommons@Fairfield by an authorized administrator of DigitalCommons@Fairfield. It is brought to you by DigitalCommons@Fairfield with permission from the rightsholder(s) and is protected by copyright and/or related rights. You are free to use this item in any way that is permitted by the copyright and related rights legislation that applies to your use. For other uses, you need to obtain permission from the rights-holder(s) directly, unless additional rights are indicated by a Creative Commons license in the record and/or on the work itself. For more information, please contact digitalcommons@fairfield.edu. 


\begin{abstract}
Applying the Ignatian Pedagogical Paradigm
to the Creation of an Accounting Ethics Course

by
\end{abstract}

Jan Van Hise and Dawn W. Massey

Published in: Journal of Business Ethics (2010) 96:453-465

Please consider for Teaching Business Ethics section. 
Ignatian Accounting Ethics Course 
Applying the Ignatian Pedagogical Paradigm

to the Creation of an Accounting Ethics Course

\begin{abstract}
This paper explains how and why the Ignatian Pedagogical Paradigm (IPP), a 450-year old approach to education, can serve as a framework for a modern principlesbased ethics course in accounting. The IPP takes a holistic view of the world, combining five elements: context, experience, reflection, action and evaluation. We describe the components of the IPP and discuss how they align with suggestions from prior research for providing principles-based ethics instruction in accounting. We conclude by describing how we used the IPP as a framework to create a graduate-level accounting ethics course.
\end{abstract}

Keywords: Accounting, Education, Ethics, Ignatian Pedagogical Paradigm 
Applying the Ignatian Pedagogical Paradigm

to the Creation of an Accounting Ethics Course

\section{Introduction}

Following the spate of scandals that plagued the accounting profession at the start of the $21^{\text {st }}$ century, the number of calls for more ethics education within the accounting curriculum increased. In response, our university chose to create a stand alone accounting ethics course in our graduate M.S.-Accounting program to be taught starting in Fall 2006.

At the time, there were only a handful of such courses in existence. A review of the syllabi for several of these courses revealed a general lack of consensus as to the appropriate make up of the course. As a result, we made the decision to start anew, researching the literature on ethics instruction in accounting. In the process, we were struck by the alignment of its varied suggestions with the Ignatian Pedagogical Paradigm (IPP), about which we had prior knowledge. Thus, we opted to use the set of five components of the IPP - context, experience, reflection, action and evaluation - as a cohesive guide in creating our accounting ethics course. Hence, our purpose in this paper is to discuss how and why the IPP can serve as a framework for creation of an accounting ethics course and to chronicle the accounting ethics course we developed using the IPP as a framework.

The next section of the paper describes the IPP. The third section includes a brief review of the literature on teaching ethics in accounting, discussing how suggestions from varied sources align with the IPP. Finally, we describe our IPP-guided accounting ethics course. 


\section{The Ignatian Pedagogical Paradigm}

The Ignatian Pedagogical Paradigm (IPP) is based on the Spiritual Exercises of St. Ignatius of Loyola, the founder of the Society of Jesus (commonly known as the Jesuits). The Jesuits adapted the IPP early in the history of the order. In 1599, the first official version of the Ratio Studiorum (Latin for "plan of studies") (Ratio) was completed. ${ }^{1}$

In the ensuing four hundred years, Jesuit institutions of learning all over the world adopted the educational system laid out in the Ratio. A $400^{\text {th }}$ anniversary edition of the Ratio (Duminuco) was published in 2000. It included as appendices two statements on Jesuit Education that previously had been published as separate monographs:

Characteristics of Jesuit Education (International Commission 1986), which has been described as the "vision" of Jesuit education; and Ignatian Pedagogy: A Practical Approach (JSEA 1993), which has been described as the "method" of Jesuit education. ${ }^{2}$ Taken together, these documents provided what the Jesuits termed, "our way of proceeding" in providing education in the Ignatian tradition.

In its Characteristics of Jesuit Education, the International Commission (1986) sets forth distinguishing features of Jesuit education. Among them are the following, which state that Jesuit education:

- Insists on individual care and concern for each person

- Assists in the total formation of each individual within the human community

- Is value-oriented

- Pursues excellence in its work of formation

- Relies on a spirit of community

- Encourages life-long openness to growth ${ }^{3}$ 
Perhaps more importantly, however, JSEA (1993) addresses the question of how to incorporate these characteristics into education. According to JSEA (1993), there are five components to the IPP. The central three components - experience, reflection and action - change the role of both teacher and learner in that the teacher is "to accompany the learner in their (sic) growth and development" (Duminuco 2000, 240). Hence, "the teacher is not merely to inform, but to help the student progress in the truth" (JSEA 1993, 9, quoting Charmot, S.J.). The IPP's final two components, which envelope the central components, are context and evaluation. Taken together, these five components shape courses taught in accordance with the IPP. Each of these five is discussed in turn.

\section{Context}

Context or "personal care and concern for the individual, which is a hallmark of Jesuit education, requires that the teacher become as conversant as possible with the life experience of the learner" (JSEA 1993, 35). In this way, the teacher considers the life circumstances of the learners and adapts the lessons in light of those circumstances.

As a first step, this requires that the teacher learn about the students' lives. For example, graduate students have different life experiences than undergraduates; full-time students are experiencing different pressures in their lives than part-time students; those who are financing their education are in a different place than those for whom education is being financed by an employer or relative. ${ }^{4}$

With knowledge about students' life experiences, the teacher can incorporate in the course material the students can relate to their own lives. Likewise, context may also require a change in the methods used to deliver the material. For instance, context requires that teachers provide an environment that is conducive to learning given the circumstances of the students' 
lives. Thus, students who cannot attend a traditional class on campus as a result of a disability, an out-of-town work assignment, or any other reason may be able to participate in an on-line class. So a necessary second step in order to incorporate context is to adapt the content and delivery of lessons to reflect the conditions of the students' lives. Ideally, knowledge of the context of students' lives allows the teacher to engage the students' feelings, imagination and intellect to generate true growth.

\section{Experience}

Experience in the Ignatian sense means something more than just lived history. The IPP describes experience as "to taste internally" (Duminuco 2000, 294). More formally, learning pursuant to the IPP, "is expected to move beyond rote knowledge to the development of the more complex learning skills of understanding, application, analysis, synthesis, and evaluation.... We use the term experience to describe any activity in which, in addition to a cognitive grasp of the matter being considered, some sensation of an affective nature is registered by the student...." (JSEA 1993) This definition of experience is akin to Bonwell and Eison's (1991, iii) notion of active learning which they define as, "instructional activities involving students in doing things and thinking about what they are doing."

Learning activities that engage head and heart (intellect and affect to use the Ignatian terms) coincide with the IPP's notion of experience. Further, because students especially need to encounter uncertainty in order to become comfortable in the unknown, learning activities that take the students outside of their comfort zones are also appropriate. Thus, faculty can include in their courses active learning experiences that put students in unfamiliar settings, or force them to confront situations that challenge their existing belief structures. In addition, discussion of cases in which significant uncertainty is present is also warranted. 


\section{Reflection}

The IPP defines reflection as "a thoughtful reconsideration of some subject matter, experience, idea, purpose or spontaneous reaction, in order to grasp its significance more fully" (JSEA 1993, 49). Reflection is the key element that distinguishes Ignatian pedagogy from more traditional learning models. In accordance with the IPP, the teacher's role is to provide the student with new information and experience. By then guiding the student to reflect on these experiences, the hope is to generate future action.

Ignatian reflection requires students to consider what the material means to them individually; to personally appropriate it. Ideally, once they have contemplated the material, and the impact it has both on them and the world around them, they will be moved to action - the next tenet of the IPP. In this ideal situation, Ignatian education leads to the transformation of the learner. Action

Action is the desired outcome of the learning experience. However, as noted above, the IPP is more about transformation than immediate action. It involves two steps: interiorizing and externally manifesting choices. In interiorizing, "in light of [students'] cognitive understanding of the experience and the affections involved (positive or negative), the will is moved." (JSEA 1993, 260). Interiorizing, thus, can be likened to an internalization of beliefs. In externally manifesting choices, the "meanings, attitudes, values which have been interiorized, made part of the person, impel the student to act, to do something consistent with the new conviction" (JSEA 1993, 261). Hence, action refers to the students' internalization of beliefs which, in turn, drive them to act in a manner consistent with those beliefs.

The goal is not only to educate, but to change the person to be a better, more caring accountant, lawyer, businessman, etc. Ideally, the educational experience leads the learner to act 
in "the service of others" (International Commission 1986). This concept is consistent with the notion of increased professionalism in business settings ${ }^{5}$ and, in public accounting, the "public watchdog" function first invoked by the Supreme Court in $1984 .^{6}$ Thus, action, which in the case of accounting might include the notion of serving the public interest, can be a theme woven into the content of the course.

\section{Evaluation}

The concept of evaluation, as included in the IPP, might best be compared to the Association to Advance Collegiate Schools of Business' (AACSB's) more recent focus on assessment of learning outcomes. Evaluation in the Ignatian sense goes beyond traditional assessment measures. The IPP suggests that in addition to evaluating students' proficiency in the subject area, the teacher should also be attuned to the students' moral growth and maturation. Thus, additional questions for the teacher to consider include: Are students more caring? Less biased? More likely to engage in the service of others? Ideally, students who show moral growth and maturation would take conscious action to confront injustice. However, consistent with the cognitive-developmental perspective (Rest 1986), changes in students' moral behavior may not be observable in a short timeframe. Instead, changes leading to behavior - such as heightened awareness of moral issues and an increased intention to address those issues are more likely to be evident in the near term.

The American Association of Jesuits Colleges and Universities (AJCU) offers the following observation on evaluation: "Observant teachers will perceive indications of growth or lack of growth in class discussions and students' generosity in response to common needs much more frequently" (AJCU 2005). Hence, evaluation, in which faculty measure the degree to which 
Ignatian Accounting Ethics Course

students' professionalism increases, is an important element of business courses taught in the tradition of the IPP.

\section{Teaching Accounting Ethics}

Although there is widespread agreement about the need for accounting students to receive additional ethics instruction (e.g., Blanthorne, et al. 2007; Haas 2005; Mintz 2007; NASBA 2005, 2007; Waddock 2005), we lack a "model curriculum" (see, e.g., Blanthorne et al. 2007; Hurtt and Thomas 2008; Loeb 1988, 1990, 1993, 2007; Loeb and Rockness 1992; Mintz 1990; Swanson 2005). Nonetheless, of the increasing number of accounting ethics studies published in recent years (Bernardi and Bean 2007), a fair number relate to accounting ethics instruction. Of those, many provide specific recommendations for elements that should be included in accounting ethics courses. Below, we include the relevant recommendations, organizing the discussion according to the five components of the IPP: context, experience, reflection, action and evaluation.

\section{Context}

Accounting ethics research has long considered the importance of context in affecting professionals' ethical decision process (see, e.g., reviews of the literature by Jones, et al. 2003 and Louwers, et al. 1997). For example, Jeffrey and Weatherholt (1996) find differences in auditors' ethical decision processes across different offices of the largest auditing firms. Similarly, Douglas, et al. (2001) find an association between corporate ethical culture and accountants' ethical sensitivity while Ponemon and Gabhart (1990) find that job-related pressures affect auditors' independence decisions. Similarly, researchers have found that pressure from peers affects not only auditors' intention to act 
ethically (Lord and DeZoort 2001; Shafter, et al. 1999) but also their ultimate ethical behavior (Ponemon 1992).

Given these findings, coupled with Loeb's $(1988,2006)$ suggestion that ethics courses should "set the stage for" a change in students' ethical behavior, in designing an accounting ethics course, it is important for faculty to consider the students' life circumstances and adapt the course accordingly. Indeed, Massey and Thorne $(2006,114)$ advocate "the use of an individualized approach to the ethical training and education of accountants...in contrast to the 'one-size-fits-all' approach inherent in many traditional ethics courses and interventions where the instructor determines course content and delivery independent of the individuals who enroll in the course." Such an approach - in which courses are tailored for students' individual life circumstances - is consistent with the IPP's recommendation to consider context in course content and delivery.

\section{Experience}

Several researchers have recommended "interactive" and "experiential" learning experiences as means of teaching accounting ethics (Loeb 2006; see also Coyne, et al. 2005; Dellaportas 2006; Loeb 1998; and Loeb and Ostas 1997). The case study method is the most commonly recommended method (e.g., Blanthorne, et al. 2007; Hiltebeitel and Jones 1991; Kerr and Smith 1995; Langenderfer and Rockness 1989; Loeb 1988; Mintz $1990,1995)$. In the case study method, students are provided with a brief overview of a situation, "along with descriptive information that both establishes a context for the problem and identifies the major decision that must be made" (Bonwell and Eison 1991, 38). Case studies not only utilize a decision-making model that "both fosters higher-order thinking and sends a clear message to students that real problems have no 'right' or 
'wrong' answers", but also capture students' interest by eliciting affective reactions from the students (Bonwell and Eison 1991, 39).

Likewise, because "an individual with an ethics related experience can bring firsthand real life discussions about the topic to the classroom" (Loeb and Ostas 2000, 231), another approach that is effective in eliciting affective responses from students is for students to interact directly with those who have confronted ethical challenges. Prior research supports using good exemplars (i.e., "heroes") and bad exemplars (i.e., "villains") to provide a context for ethics issues and positive (or negative) role models to emulate (or not) in teaching ethics to accounting students (e.g., Armstrong, et al. 2003; Coyne, et al. 2005; Dobson and Armstrong 1995; and Knapp, et al. 1998).

Additionally, providing students with collaborative learning opportunities - in which students learn from each other - is another active learning technique that finds support in accounting ethics research. For example, both Brugman and Weisfelt (2000) and Thorne and Hartwick (2001) report changes in auditors' ethical judgments following discussion of an ethical dilemma with peers. Loeb (1998) similarly recommends incorporating student presentations - particularly those that utilize "alternative techniques" (e.g., creative approaches such as mock trials, role plays and debates) - in teaching ethics to accounting students (see also Loeb and Ostas 2000).

All of these approaches - case studies, interaction with ethics exemplars and collaborative learning - involve a sharing of experiences and treat students as active participants in the learning process. In so doing, the approaches are consistent with the IPP's recommendation to include experience in course content and delivery. 


\section{Reflection}

Mintz (2006a) recommends a reconsideration of what one has done or is doing reflection - in accounting ethics instruction for its ability to slow the learning process and facilitate students' internalization of the learning (i.e., promote "deep learning"). Similarly, Burns (2006) suggests reflection as appropriately covered in capstone courses that include ethics content.

Mintz (2006a, 112) states, "Reflective learning enables students to evaluate the meaning of new ideas and situations based on prior understandings and it helps to transform their thinking." To some degree, case studies and knowledge of ethics exemplars provide students with the opportunity to reconsider the actions of those involved in the respective ethical situations. However, not all students will engage in reflection without an express requirement to do so. It is for this reason that Mintz (2006a) requires written reflections in his accounting ethics course, which coincides with the IPP's recommendation to include reflection in course delivery.

\section{Action}

One hallmark of the accounting profession is its public service orientation (c.f., Zeisel and Estes 1979). According to Kirk (1984), accountants are expected to uphold both technical and ethical standards in order to "protect the public by assuring objectivity and integrity on the part of preparers and auditors of financial reports."

For this reason, several researchers recommend inclusion of codes of conduct, such as the Code of Professional Conduct, in accounting ethics courses (e.g., Karnes and Sterner 1988; Loeb 1998, 2006; and Mintz 1990; see also Blanthorne, et al. 2007). As Loeb (2006) points out, including coverage of ethics codes in the accounting curriculum 
can foster students' ability to recognize issues in accounting that have ethical implications. Thus, inclusion of codes of conduct in accounting ethics courses is consistent with the IPP's inclusion of action in course content.

\section{Evaluation}

In designing courses, faculty should determine, ex ante, how they will assess course efficacy (e.g., Lavoie and Rosman 2007). In the literature on teaching accounting ethics education, several researchers note the need to develop evaluative measures that are consistent with the objectives of the course (Hiltebeitel and Jones 1992; Loeb 1991; Shawver 2006). At the same time, the researchers note that traditional measures of student learning are insufficient to capture the unique goals of accounting ethics education, such as enhancing students'

professionalism (Loeb 1991; Shawver 2006). Importantly, "a sensitivity to the ethical ramifications of its activities allows a profession to display its commitment to public service, thereby setting itself apart from the unabashed self-interestedness of the business firm" (Osiel 1984, 44; see also Coyne, et al. 2005; Mintz 1990). Hence, evaluating changes in students' ethical sensitivity represents a viable option in assessing enhancements in students' professionalism and is consistent with the IPP's notion of evaluation, in which faculty measure the degree to which students' professionalism increases.

\section{Conclusion}

Taken together, the literature on teaching ethics in the accounting curriculum supports a student-centered approach. Various active learning approaches (case studies, exposure to exemplars, collaborative learning), and the use of reflection are also suggested. Likewise, the literature on teaching ethics in the accounting curriculum supports exposing students to The Code of Professional Conduct and a focusing on 
professionalism and assessment approaches that measure students' progress in meeting the goals. These IPP-consistent approaches serve as a basis for the accounting ethics course we developed, which we discuss in the following section.

\section{Creating the course}

Drawing on Lavoie and Rosman (2007) and Massey and Van Hise (2003), several key decisions should be made in developing any successful accounting course:

1. The objective of the course;

2. The content to include in the course;

3. The delivery methods to use in the course; and

4. The methods that will be used to evaluate course efficacy.

In the following subsections, we briefly discuss how the IPP served as a guide in making each of these decisions.

\section{Course objectives}

Understanding the context of our students' lives helps to determine the appropriate objective for the course. Previous research suggests that students are ethically formed by the age of majority (Alsop 2006). Additionally, Hanson (1987) comments that you cannot convert a "deviant" to a "virtuous human being" by instructing him in ethics. Even within the accounting literature, there has not been much encouragement. Ponemon (1993) and Lampe (1996) both report that ethics education may be ineffective in affecting moral development.

Rather, as suggested by prior ethics research (c.f., Loeb 1988, 1991, 2006; Shawver 2006), improving students' professionalism is the primary objective of the course. However, increasing students' professionalism in public accounting is not 
sufficient. Previous research reports that national CPA firms experience turnover rates well in excess of $15 \%$ per year (Bufe and Murphy 2004). Given this high turnover, most graduates will spend few years of their careers in public accounting, and many years outside public accounting practice. Together with the Ignatian passion for lifelong learning (International Commission 1986), the extent of accountants' careers spent outside public accounting, suggests that it is important to prepare the students for situations they will encounter across the spans of their entire careers and develop their professionalism to deal with situations both within and beyond public accounting.

A secondary objective also becomes apparent. Spitzer (2005) has called for a return to principles-based instruction, which seems particularly relevant in light of the calls for principles-based approaches to accounting in the U.S. (see, e.g., SEC 2003). Hence, a secondary objective is to enhance the students' ethical decision-making skills, and especially their use of ethical principles in these decisions.

\section{Course Content}

Course content relates to decisions about what material will be taught (Massey and Van Hise 2003). However, before addressing specific areas in which ethical dilemmas arise, the students must first must become familiar with a coherent set of principles upon which their decisions can be based if they are to make principles-based decisions (Armstrong 1993). As a result, the first content to be covered is a review of four classic philosophical approaches to ethics: consequential, nonconsequential, virtue and justice theories.

In addition, we also introduce the students to two more experiential principled decision making approaches that are derived from Ignatian spirituality: Ignatian 
discernment and Lonergan’s concept of “questing” (Neilsen and Stebbins 2000; Baird 2005). While Ignatian discernment explicitly includes a spiritual element in the decisionmaking process, Lonergan's process is very similar to discernment but does not explicitly include this element. ${ }^{7,8}$

Those in professions have an additional source of guidance in ethical dilemmas beyond those provided by ethical theory - namely, professional codes of ethics. Most graduate accounting students have already learned much about the public accounting profession's Code of Professional Ethics from previous classes. For example, in auditing classes, coverage of the code typically requires students to memorize individual sections of the code. However, the IPP suggests that Jesuit education should not be based on simplistic content knowledge such as that obtained via rote memorization, but should instead foster "more complex learning skills of understanding, application, analysis, synthesis, and evaluation" (JSEA 1993). Consequently, in covering the code, we focus on normative considerations.

For instance, the first issue the students address about the Code of Professional Ethics is the appropriate form of a code of ethics for the accounting profession. Should it be a list of "thou shalt nots", or an affirmative statement of expectations? Further, the discussion is not limited to a code of ethics for the public accounting profession; codes of ethics for a for-profit business, for a not-for-profit entity and for a governmental agency are also topics of discussion. In small groups, students wrestle with questions about the nature of a profession, and whether a different standard of behavior should be expected of "professionals." 
Once the guidance for ethical decision-making has been considered, the course turns to areas within business practice that often produce ethical dilemmas. Among these are leadership and corporate governance, including consideration of executive compensation, misstatement of financial statements, and international business practices.

Whistle blowing is another common topic in accounting ethics classes, especially since the trio of famous whistle blowers graced the cover of Time magazine as "persons of the year." Our focus in this course is not to talk about famous examples of whistle blowing, but rather to consider the decision to become a whistle blower. Students wrestle with decisions including when it is okay, or even necessary, to blow the whistle, or when the desire for self-preservation should win out. In this way, students are also able to gain insight into what would make a company's whistle blowing hotline successful.

While most of the students are familiar with whistle blowing in general, few have considered the ramifications blowing the whistle could have on their own lives. Here they have a chance to grapple with the unknown. How long could I continue to pay the bills if I'm fired after I blow the whistle? Where will I get the money to hire a lawyer to sue to get my job back? Would I want to work for that company again after the way it treated me? These questions became both very real and very personal for the students as they consider the decision to blow the whistle.

Finally, the class considers several topics that dwell in the region of accounting generally labeled "non-traditional": social responsibility accounting, privacy audits, and environmental accounting. These topics clearly appeal to the affect much more than the intellect, especially since the academic accounting literature in all three of these areas is relatively undeveloped. 


\section{Course Delivery}

Course delivery relates to decisions about how the material will be taught (Massey and Van Hise 2003). In our class, there are three key elements to course delivery, each of which will be discussed below: considering the classroom as a community, utilizing active learning techniques and incorporating reflection.

\section{Considering the Classroom as Community}

As noted previously, Jesuit education stresses the value of community in learning (International Commission 1986). Hence, context also extends beyond course objectives to creating a conducive environment in which learning can take place. Our course is designed as part of our MSA program, which is a full-time cohort graduate accounting program. Thus, the educational model into which the course is embedded is built on the

concept of "community."10 Further, in the Ignatian model, the instructor accompanies the learners rather than leading them, so the instructor also clearly must be a part of the learning community.

\section{Utilizing Active Learning Techniques}

The IPP strives to integrate affective and intellectual development, in order to maximize growth in the learner. Moreover the IPP suggests that experiential learning is a key to generate this integrative growth. Dellaportas (2006) reports: "The process of interactive exchange with students, combined with moral problem solving, appears to speed up the natural development of moral judgment." This suggests that the Igantian emphasis on active learning techniques is wholly appropriate for an ethics class. As a result, the course incorporates a number of active learning techniques - including, case 
studies, interaction with ethics exemplars, collaborative learning and use of IPP-linked decision making techniques - each of which is discussed below.

Case studies. In accordance with the IPP notion of experience, we include in the course case studies that focus on ethical dilemmas to which the students can relate. The cases connect the classroom material to the "real world," thus preparing the students for lifelong learning.

As noted previously, students will develop a deeper connection with the material if they are able to make personal connections with it. Thus, for example, some of the ethics cases deal with situations that the students might already have encountered in their work experience. For others that went beyond the level of the students' experience, we draw the students into the cases by their sordid details, cheating spouses for example. All the cases are based on true situations, and oftentimes take the students out of their comfort zones so as to give them experience in dealing with uncertainty.

In case analysis sessions, students discuss the dilemma they perceive and "talk though" a recommended course of action. To justify their decisions, students are required to explain their reasoning (Armstrong 1993). Additionally, to strengthen their critical thinking skills (Albrecht and Sack 2000), and consistent with the Ignatian emphasis on values in education, in their justifications, the students have to draw upon the philosophical ethical theories we have covered in the class. Often the class does not come to a consensus on the proper course of action, forcing the students to dwell in uncertainty. All the while, the instructor accompanies the students, rather than leading them, asking probing and/or controversial questions and being careful not to interject her personal opinion into the discussion. 
Interaction with ethics exemplars. To expose the students to ethics exemplars, we include guest speakers in our course to share with the students ethical dilemmas they have encountered. More poignantly, however, we include in the course an interview assignment in which students are required to interview someone who has encountered a significant ethical dilemma and report on it in a written paper. ${ }^{11}$ The students not only report on the dilemma, but also evaluate how the interviewee handled the dilemma, and address what they personally would have done if they were in the same situation. After conducting the interview and writing their papers, the students also briefly present their papers to the class. As with the case analyses, the interviews not only connect the students with the "real world", but also frequently expose the students to uncomfortable topics (e.g., assisted suicide, infidelity, etc.) and thus give the students an additional opportunity to deal with uncertainty.

Collaborative learning. In order to facilitate the students' collaborative learning, the course is offered in a seminar format; the students lead all the classes after the first meeting. Each student is required to review a lesson plan with the instructor to ensure that appropriate material will be covered. However, in order to assure that the students continue to employ active learning in the classes for which they are responsible, they are graded both on the content they present as well as on how well they involve their classmates in the class. As a result, they have used a wonderful collection of imaginative games, role-playing, debates, and group work.

Decision-making in accordance with the IPP. Both discernment, and its counterpart questing, involve a prescribed four-step process in which the decision maker, informed by his/her internalized beliefs, systematically considers all stakeholders, 
possible courses of action, and outcomes. Although discernment can be described in writing, (Moberg and Calkins 2001) reading about discernment does not teach one how to do it; discernment is a skill that can only be perfected by practice. As a result, the students are invited to practice discernment over the course of the semester in considering numerous ethical dilemmas discussed in the course. Similarly, those who are not comfortable with the spiritual dimension in discernment were invited to practice decision-making using Lonergan’s “questing” approach (Nielsen and Stebbins 2000; Baird 2005).

\section{Incorporating Reflection}

Reflection - tied to experience and leading to action - is a key, if not the key component of the Ignatian paradigm. Moreover, the use of reflection in accounting education has gained increasing support in the accounting literature (Burns 2006, Mintz 2006a). The inclusion of a reflection requirement in the course is pivotal in the integration of affective and intellectual knowledge. The students are given a series of reflective questions to prompt them to engage with the affect the material they have covered in class each day. These questions include:

- What aspects of the class most deeply affected me? Why?

- What aspects of the class are most relevant to me and my life? Why?

- If there wasn't anything in class that touched me or seemed relevant, why wasn't there?

Using these questions as guides, the students are required to submit a reflective paper within 48 hours after each class. ${ }^{12}$ The 48 -hour requirement forces the students to reflect on the material while it is still fresh in their minds, and prevents them from 
manufacturing a "reflection" the night before the next class to "check a box." The reflection papers account for approximately $25 \%$ of the semester grade. In addition to the reflection papers, the students are required to include reflections in each of their written case analyses, and in the interview assignment.

The reflection papers also serve as the bridge from one class to the next. Although the reflections are submitted confidentially to the instructor, any unusual questions or common sentiments that arose in the reflections are reported at the beginning of the next class (with the permission of the authors of those comments).

\section{Evaluation}

We employ traditional and novel means of evaluating our course. From a traditional perspective, the students complete both objective and open-ended traditional course evaluations at the end of each semester. On these, the students have reported that in-class discussions and reflective papers are the two aspects of the course that they believed contribute most to their learning.

In addition, we also employ a novel approach in evaluating our course. That is, we evaluate each of the main goals of our course, consistent with the counsel offered by accounting ethics researchers to do so. We discuss each, in turn, below.

\section{Professionalism}

Consistent with prior research, we seek in our course to "set the stage" for professional growth (c.f., Loeb 1988, 2006; Shawver 2006). Because reflection pursuant to the IPP is transformative and moves the students to action so that they might be more inclined to act in a professional manner should they find themselves with the opportunity to do so, the reflection 
papers play a large role in evaluation. By reviewing the students' reflections over the semester, we are able to gauge the students' personal growth.

Further, because prior research links professionalism to ethical sensitivity (Coyne, et al. 2005; Mintz 1990; Osiel 1984), we evaluate changes in students' professionalism through differences in ethical sensitivity as assessed via pre and post administrations of Forsyth's (1980) Ethics Position Questionnaire (EPQ). ${ }^{13}$ Students' idealism (relativism) scores on the EPQ have increased (decreased), suggesting improvements in ethical sensitivity.

\section{Ethical Decision-Making Skills}

The cases and interview assignment facilitate our review of student success in this area in two ways. First, each of these assignments requires the students to synthesize their knowledge and critically evaluate the actions of another. Second, the case analyses and the interview assignment provide the instructor with a means of evaluating changes in students' ability to utilize the philosophical ethical theories they have learned in the class in evaluating a ethical dilemmas.

Although improvement in discerning is difficult to assess, students anecdotally have reported in their confidential reflections not only that they have become more comfortable discerning decisions, but also that the approach helped them to better process decisions.

\section{Conclusion}

The Ignatian Pedagogical Paradigm (IPP) is a 450-year old approach to education. It includes five components that are consistent with many modern pedagogical approaches: context, experience, reflection, action and evaluation. Indeed, the elements of the IPP are not unique. For instance, the use of active learning techniques and 
reflection especially are widely supported in the accounting educational literature (Burns 2006; Coram 2005; Mintz 2006a). Moreover, both feminist pedagogy (hooks 1994) and adult education theory (Brookfield 1991) support a collaborative approach to education, as did Mintz (1995) in an earlier article on ethics education in accounting. Further, more recent literature has demonstrated how Ignatian pedagogy is compatible with and contributes to higher education pedagogy (DeFeo 2009).

However, it is precisely because of its utility to college teaching and because it shares many of the recommendations in the accounting ethics education literature that we recommend the IPP as a unified framework for developing our graduate accounting ethics course. By using the IPP, we have developed a course that not only teaches the basics of ethics in accounting, but also reflects care for each individual student (what is commonly referred to as "cura personalis"), focuses on developing the whole student, and not just the intellect, develops and supports community in the classroom, includes a focus on values, stresses excellence, and stimulates a desire for life-long learning. 


\section{References}

Albrecht, W. and R. Sack. 2000. Accounting education: charting the course through a perilous future. Accounting Education Series 16. Sarasota, Florida: American Accounting Association.

Alsop, R. 2006. Business ethics education in business schools: A commentary. Journal of Management Education. 30, 1(February): 11-14.

Armstrong, M.B. 1993. Ethics and professionalism in accounting education: A sample course. Journal of Accounting Education. 11 (1): 77-92.

Armstrong, M.B., J. Ketz and D. Owsen. 2003. Ethics education in accounting: Moving toward ethical motivation and ethical behavior. Journal of Accounting Education, 21: 1-16.

Association of Jesuit Colleges and Universities (AJCU). 2005. Jesuit Education and Ignatian Pedagogy September 2005. Available at: http://www.ajcunet.edu/JesuitEducation-and-Ignatian-Pedagogy. Last visited on June 5, 2009.

Baird, C. 2005. Everyday Ethics: Making Hard Choices in a Complex World. Denver, CO : Tendril Press.

Bernardi, R. and D. Bean. 2007. The growth of accounting research in ethics journals: a 45-year study. Research on Professional Responsibility and Ethics in Accounting. 11: 47-61.

Blanthorne, C., S. Kovar, and D. Fisher. 2007. Accounting educators' opinions about ethics in the curriculum: An extensive view. Issues in Accounting Education. 22 (3, August): 355-390. 
Bonwell, C. and J. Eison, 1991. Active Learning: Creating Excitement in the Classroom. ASHE-ERIC Higher Education Report No. 1. Washington, DC: The George Washington University, School of Education and Human Development.

Brackley, D. 2004. The Call to Discernment in Troubled Times. NY: Crossroad Publishing.

Brookfield, S. 1991. Understanding and Facilitating Adult Learning. San Francisco: Jossey-Bass.

Brugman, D., and M. Weisfelt. 2000. Moral competence and professional reasoning of Dutch accountants. Research on Accounting Ethics 7: 103-140.

Bufe, B. and L. Murphy. 2004. How to keep them once you've got them. Journal of Accountancy. December: 57-62.

Burns, C. 2006. The evolution of a graduate capstone accounting course. Journal of Accounting Education. 24: 118-133.

Challies, T. 2007. The Discipline of Spiritual Discernment. Wheaton, IL: Crossway Books.

Coram, P. 2005. Active learning in accounting: A case study in preaching to the unconverted. Accounting Research Journal. 18: (1) 13-20.

Coyne, M., D. Massey and J. Thibodeau. 2005. Raising students' ethical sensitivity with a value relevance approach. Advances in Accounting Education. 7: 173-207.

DeFeo, J. 2009. Old wine in new skin: Ignatian Pedagogy, compatible with and contributing to Jesuit Higher Education. Fordham University. Unpuplished dissertation.

Dellaportas, S. 2006. Making a difference with deliberate ethics interventions. Journal of Business Ethics. 65(4): 391-404. 
Dobson, J. and M. Armstrong. 1995. Application of virtue ethics theory: a lesson from architecture. Research on Accounting. Ethics. 1: 187-202.

Douglas, R. Davidson, and B. Schwartz. 2001. The effect of organizational culture and ethical orientation on accountants' ethical judgments. Journal of Business Ethics 34: 101-121.

Duminuco, Vincent J. ed. 2000. The Jesuit Ratio Studiorum of 1599: 400 ${ }^{\text {th }}$ Anniversary Perspectives. New York: Fordham University Press.

Forsyth, D. 1980. Taxonomy of ethical ideologies. Journal of Personality and Social Psychology. 39 (July): 175-184.

Haas, A. 2005. Now is the time for ethics in education. The CPA Journal. 75 (6, June): 66-68.

Hanson, K. 1987. What good are ethics courses? Across the Board (September): 10-11.

Hiltebeitel, K. and S. Jones. 1991. Initial evidence on the impact of integrating ethics into accounting education. Issues in Accounting Education, 6 (2, Fall): 262-275.

Hiltebeitel, K., and S. Jones. 1992. An assessment of ethics instruction in accounting education. Journal of Business Ethics 11: 37-46.

hooks, b. 1994. Teaching to Transgress: Education as the Practice of Freedom. New York: Routledge.

Hurtt, R. K., and C. W. Thomas. 2008. Implementing a required ethics class for students in accounting: The Texas experience. Issues in Accounting Education. 21 (1, Feb.): 31-51.

International Commission on the Apostolate of Jesuit Education, Jesuit Secondary Education Association (International Commission). 1986. Go Forth and Teach: Characteristics of 
Jesuit Education. Originally published as a monograph; reprinted in Appendix A in The Jesuit Ratio Studiorum of 1599: $400^{\text {th }}$ Anniversary Perspectives.

Jeffrey, C., and N. Weatherholt. 1996. Ethical development, professional commitment, and rule observance attitudes: A study of CPAs and corporate accountants. Behavioral Research in Accounting 8: 8-31.

Jesuit Secondary Education Association (JSEA). 1993. Ignatian Pedagogy A Practical Approach. Originally published as a monograph; reprinted as Appendix B in The Jesuit Ratio Studiorum of 1599: $400^{\text {th }}$ Anniversary Perspectives.

Jones, J., D. Massey and L. Thorne. 2003. Auditor's ethical reasoning: insights from past research and implications for the future. Journal of Accounting Literature. 22: 45103.Lampe, J. 1996. The impact of ethics education in accounting curricula. Research on Accounting Ethics. 2: 187-220.

Karcher, J. 1996. Accountants' ability to discern the presence of ethical problems. Journal of Business Ethics 15: 1033-1050.

Karnes, A. and J. Sterner. 1988. The role of ethics in accounting education. The Accounting. Educators' Journal. 1(Fall): 18-31.

Kerr, D. and L.M. Smith. 1995. Importance of and approaches to incorporating ethics into the accounting classroom. Journal of Business Ethics, 14(12): 987-995.

Ketchand, A., R. Morris, and W. Shafer. 1999. An analysis of the role of moral intensity in auditing judgments. Research on Accounting Ethics 5: 249-270.

Kirk, D. 1984. Standards and other requisites of professionalism. Saxe Lectures in Accounting. CUNY-Baruch. NY: April 26. 
Knapp, M., T. Louwers and C. Weber. 1998. Celebrating accounting heroes: an alternative approach to teaching ethics. Advances in Accounting Education 1: $267-277$.

Lampe, J. 1996. The impact of ethics education in accounting curricula. Research on Accounting Ethics. 2: 187-220.

Langenderfer, H. and J. Rockness. 1989. Integrating ethics into the accounting curriculum: Issues, problems, and solutions. Issues in Accounting Education. 1 (Spring): 58-69.

Lavoie, D., and A. Rosman. 2007. Using active student-centered learning-based instructional design to develop faculty and improve course design, delivery and evaluation. Issues in Accounting Education. 22 (1, February): 105-118.

Loeb, S. 1988. Teaching students accounting ethics: some crucial issues. Issues in Accounting Education. 3 (Fall): 316-329.

Loeb, S. 1990. Whistleblowing and accounting education. Issues in Accounting Education. 5 (Fall): 281-294.

Loeb, S. 1991. The evaluation of outcomes of accounting ethics education. Journal of Business Ethics 10 (February): 77-84.

Loeb, S. 1993. FM Forum: On financial ethics. In: J.S. Ang (ed.) Financial Management. 22 (Autumn): 53-59.

Loeb, S. 1998. A separate course in accounting ethics: An example. Advances in Accounting Education. 1: 235-250.

Loeb, S. 2006. Issues relating to teaching accounting ethics: An 18 year retrospective. Research on Professional Responsibility and Ethics in Accounting 11: 1-30. 
Loeb, S. and D. Ostas. 1997. A business ethics experiential learning module: The Maryland business school experience. Teaching Business Ethics 1 (1): 21-32.

Loeb, S., and D. Ostas. 2000. The team teaching of business ethics in a weekly semester long format. Teaching Business Ethics. 4 (3, August): 225-238.

Loeb, S., and J. Rockness. 1992. Accounting ethics and education: A response. Journal of Business Ethics. 11 (7, July): 485-490.

Lord, A., and F. T. DeZoort. 2001. The impact of commitment and moral reasoning on accountants' response to social influence pressures. Accounting Organizations and Society 26: 215-235.

Louwers, T., L. Ponemon, and R. Radtke. 1997. Examining accountants' ethical behavior: A review and implications for future research. In Behavioral Accounting Research: Foundations and Frontiers, ed. V. Arnold and S. Sutton, 48-88. Sarasota, FL: American Accounting Association.

Massey, D. and L. Thorne. 2006. The impact of task information feedback on ethical reasoning. Behavioral Research in Accounting. 18: 103 - 116.

Massey, D., and J. Van Hise. 2003. Creating a custom-published textbook to facilitate curriculum change. Advances in Accounting Education: Teaching and Curriculum Innovations. 5: 243-261.

Mintz, S. 1990. Ethics in the management accounting curriculum. Management Accounting. 71 (12, June): 51-54.

Mintz, S. 1995. Virtue ethics and accounting education. Issues in Accounting Education. $10(2): 247-67$. 
Mintz, S. 2006. Accounting ethics education: Integrating reflective learning and virtue ethics. Journal of Accounting Education. 24: 97-117.

Mintz, S. 2007. Loeb's contribution to accounting ethics education and research. Research on Professional Responsibility and Ethics in Accounting. 11: 31-46.

Moberg, D. and M. Calkins. 2001. Reflection in Business Ethics: Insights from St. Ignatius' Spiritual Exercises. Journal of Business Ethics. 33 (3): 257-70.

National Association of State Boards of Accountancy (NASBA). 2005. Education Committee Task Force Framework, "UAA Education Rules 2005 Exposure Draft," Nashville, Tennessee.

National Association of State Boards of Accountancy (NASBA). 2007. "Rules 5-1 and 52 Exposure Draft," Nashville, Tennessee.

Nielsen, M. and M. J. Stebbins. 2000. "Personal Authenticity." Chapter in Faith and Values at Work. Unpublished monograph. Washington, D.C.: Woodstock Theological Center.

Osiel, M. 1984. The politics of professional ethics. Social Policy. 15 (Summer): 43-48.

Ponemon, L. 1993. Can ethics be taught in accounting? Journal of Accounting Education. 11: 185209.

Ponemon, L. 1992. Accountant underreporting and moral reasoning: An experimental lab study. Contemporary Accounting Research 9: 171-189.

Ponemon, L. and D. Gabhart. 1990. Accountant independence judgments: A cognitivedevelopmental model and experimental evidence. Contemporary Accounting Research 7: 227-251.

Securities and Exchange Commission (SEC). 2003. A Study Pursuant to Section 108(d) of the Sarbanes-Oxley Act of 2002 on the Adoption by the United States Financial 
Ignatian Accounting Ethics Course

Reporting System of a Principles-Based Accounting System. Available on the Internet at: http://www.sec.gov/news/studies/principlesbasedstand.htm (last accessed August 8, 2009).

Shafer, W., R. Morris, and A. Ketchand. 1999. The effects of formal sanctions on accountant independence. Auditing: A Journal of Practice and Theory 18 (Supplement): 85-101.

Shawver, T. 2006. An exploratory study assessing the effectiveness of a professional responsibility course. Global Perspectives on Accounting Education. 3: available on the Internet at: http://gpae.bryant.edu/ gpae/Vol3/Study\%20Effectiveness\% 20Professional\%20Responsibility\%20Course.pdf (last accessed July 21, 2009).

Spitzer, Robert, S.J. 2005. Six Steps for Remedying Contemporary Ethical Problems. Available at: http://www.gonzaga.edu/Files/Campus+Resources/Offices+and+Services+AZ/Gonzaga+Ethics+Institute/08-13-03Best+Publication+Ethics+Paper.doc (Last visited 6-6-09).

Swanson, D. 2005. Business ethics education at bay: Addressing a crisis of legitimacy. Issues in Accounting Education. 20 (3, August): 247-253.

Thorne, L. and J. Hartwick. 2001. The directional effects of discussion on accountants' moral reasoning. Contemporary Accounting Research 18: 337-362.

Veltri, John, S.J. 2009. Decision-Making: A More Useful Format For Discerning. Available at: http://spiritualorientations.com/DecisionMaking\%20Format\% 20For\%20Personal\%20Use.htm (Last visited 6-6-09). 
Ignatian Accounting Ethics Course

Waddock, S. 2005. Hollow men and women at the helm...Hollow accounting ethics? Issues in Accounting Education. 20 (2, May): 145-150.

Zeisel, G. and R. Estes. 1979. Accounting and public service. The Accounting Review. LIV (2, April): 402-408. 


\section{Notes}

${ }^{1}$ While the Ratio does not describe the IPP as such, it includes the structure for it, and is considered the basis for Jesuit education.

${ }^{2}$ Although both were originally developed for use by Jesuit high schools, they have been applied to Jesuit higher education as well (DeFeo 2009).

${ }^{3}$ While there are twenty-eight characteristics of Jesuit education included in the formal document, we have culled here those we believe most relevant for an ethics course.

${ }^{4}$ Faculty can generally ascertain from the class roster or university registration system the students' enrollment status (e.g., graduate or undergraduate program, full-time or part-time). Faculty can also ask students about their professional backgrounds (e.g., work experiences). It is theoretically possible that faculty members will be unable to learn enough about students' lives to adequately establish context. However, in our experience, being aware of such factors as students' enrollment status and open to the information that students choose to share about their experiences has proven sufficient.

${ }^{5}$ See, e.g., BusinessDictionary.com, which defines professionalism as: "Meticulous adherence to undeviating courtesy, honesty, and responsibility in one's dealings with customers and associates, plus a level of excellence that goes over and above the commercial considerations and legal requirements." (available on the Internet at: http://www.businessdictionary.com/definition/professionalism.html, last accessed July 17, 2009).

${ }^{6}$ United States v. Arthur Young \& Co., No. 82-687, slip Opinion at 11 (March 21, 1984). 
${ }^{7}$ A discussion of discernment, and Lonergan's unique variation on it (questing), is beyond the scope of this paper. Briefly, discernment is a technique for making a decision not between good and evil, but among competing goods, by incorporation of a spiritual dimension. Questing takes a similar approach but excludes an explicit spiritual dimension. For information on discernment, see Veltri (2009). For information on Lonergan's questing see Baird (2005) and Nielsen and Stebbins (2000). ${ }^{8}$ Although discernment can be described in writing (Moberg and Calkins 2001), reading about discernment does not teach one how to do it; discernment is a skill that can only be perfected by practice (Brackley 2004; Challies 2007). As a result, the students were invited to practice discernment over the course of the semester in considering numerous ethical dilemmas discussed in the course. Similarly, those who were not comfortable with the spiritual dimension in discernment were invited to practice decision-making using Lonergan's “questing” approach (Nielsen and Stebbins, 2000; Baird 2005). ${ }^{9}$ Time Magazine's "2002 Persons of the Year" were Cynthia Cooper of WorldCom, Coleen Rowley of the FBI, and Sherron Watkins of Enron.

${ }^{10}$ Since the course is also available as an elective to MBA students who are generally older and have more diverse backgrounds than the average MSA student, they, too, must be welcomed into the learning community. Anecdotally, a number of MBA students have taken the class and have reported that they very much felt that they were part of the learning community.

${ }^{11}$ Obviously, the individuals must be willing to share their experience and, to ensure a richness of experience, we require that interviewees have worked on a full-time, basis for at least five years. To identify willing interviewees, we recommend that our students start 
by approaching friends and family using the following or similar: "I'm doing a paper on responsible business practices in the workplace. On a strictly anonymous basis, would you be willing to tell me about experiences you have had in your career that you think were important from an ethical point of view?" Once a willing interviewee is identified, we require the students to obtain the interviewees' informed consent to participate in the interview. In our experience, students have never reported problems in finding willing interviewees.

${ }^{12}$ Students were required to write a reflection after approximately $80 \%$ of classes to receive full credit. This assured that students who missed classes for legitimate reasons were not penalized.

${ }^{13}$ Another way to assess professionalism might be through utilization of test questions drawn from professional accounting resources such as AICPA training courses and the CPA exam. While such an approach can give insight into students' mastery of the Code of Professional Conduct applicable to public accountants, we opted not to use such an approach because it is not consistent with our efforts to foster students' professionalism both within and outside public accounting. 